\title{
Is er onder de Wwz nog plaats voor de ontbindende voorwaarde?
}

\author{
De ontbindende voorwaarde onder de Wwz - een korte polemiek
}

prof. mr. Jaap van Slooten*

Eén van de doelen van dit tijdschrift is het aanmakkeren van het academisch debat. Gekozen is voor de ontbindende voormaarde, een bekend en geaccepteerd leerstuk onder het oude recht maarvan het de vraag is of het onder het nieume recht bestaansrecht heeft. Faap van Slooten is gevraagd stelling te nemen en betoogt in zijn bijdrage dat dat wel het geval is. Marian van Eck is vervolgens gevraagd daarop te reageren. We hopen dat hiermee een aanzet is gegeven voor verdergaand debat, in dit tijdschrift of op andere plekken.

\section{Inleiding}

In het Mungra-arrest aanvaardde de Hoge Raad de mogelijkheid van de ontbindende voorwaarde in ons ontslagrecht. ${ }^{1}$ In het HTM-arrest negeerde hij de kritiek van literatuur en lagere rechtspraak op de Mungraleer ${ }^{2}$. Gaat de Hoge Raad in het licht van de Wwz anders oordelen?

\section{Oordeel in Mungra}

De kernoverweging van Hoge Raad luidde: 'Een ontbindende voorwaarde kan, maar behoeft niet noodzakelijk met dit stelsel [van gesloten ontslagrecht, JvS] onverenigbaar te zijn, waarbij van geval tot geval moet worden bezien in hoeverre de strekking van voormelde regels tot nietigheid van de ontbindende voorwaarde leidt.'

\section{Na Mungra}

Zoals bekend, heeft de Hoge Raad zich nog een aantal keren moeten uitlaten over de rechtsgeldigheid van een ontbindende voorwaarde, waarbij hij de voorwaarde

* Jaap van Slooten is hoogleraar arbeidsrecht aan de Universiteit van Amsterdam en advocaat bij Stibbe. Dit is een lichte bewerking van een artikel dat eerder verscheen in: P.F. van der Heijden (red.), JAR 25 jaar. een hooggeleerde selectie met annotaties verfraaid, Den Haag: Sdu Uitgevers 2016, p. 24-26.

1. HR 6 maart 1992, NJ 1992/509; JAR 1992/10.

2. HR 2 november 2012, JAR 2012/314. soms wel en soms niet geldig achtte. In het HTM-arrest herformuleerde de Hoge Raad de Mungraleer. Ik ben van mening dat hier geen sprake is van een versoepeling van Mungra en evenmin van een aanscherping. Nog steeds luidt het oordeel dat een ontbindende voorwaarde in het wettelijk stelsel van het ontslagrecht zal moeten passen (hetgeen niet snel het geval zal zijn) en dat dit van geval tot geval zal moeten worden bezien. Nieuw is de riedel over 'aard, inhoud en context van de voorwaarde'. Mijns inziens is dat een manier om de rechtspraak tot dan toe samen te vatten, waarbij zaken van belang werden bevonden als: de formulering van het beding, de vraag in wiens risicosfeer de voorwaarde valt en de vraag tegen welke achtergrond de voorwaarde is afgesproken (zoals in de HTM-casus relevant was).

\section{Lagere rechtspraak en literatuur}

De lagere rechtspraak en de literatuur zijn behoorlijk kritisch $^{3}$, ook na het HTM-arrest. ${ }^{4}$ Ik ben van mening dat de Hoge Raad om twee redenen terecht heeft vastgehouden aan de Mungraleer. Ten eerste: de Hoge Raad past niet alleen het arbeidsrecht, maar ook het algemeen vermogensrecht toe. Dat algemeen vermogensrecht erkent de ontbindende voorwaarde (vgl. artikel 6:22 BW). Zoals bekend, geldt het leerstuk van de samenloop indien er algemene en bijzondere regels van toepassing zijn. Hoofdregel is dat samenloop mogelijk is, tenzij een bepaalde regel van bijzonder recht zich hiertegen verzet. Een dergelijke specifieke regel is er niet in het ontslagrecht. Integendeel: sommige ontbindende voorwaarden worden in het ontslagrecht nog steeds verboden, waaruit de Hoge Raad in Mungra a contrario afleidde dat een ontbindende voorwaarde niet per se in strijd is met het ontslagrecht (artikel 7:667 lid 7 en 8 BW). Tegen die achtergrond is niet goed vol te houden dat een ontbindende voorwaarde altijd in strijd is met het stelsel van ontslagrecht.

Ten tweede kunnen we, 24 jaar na Mungra, wel vaststellen dat er in de praktijk door het arrest geen groot

3. A-G Timmermans in zijn conclusie voor JAR 2012/314, 3.16.

4. Y. Konijn in JAR 2012/314. 
gat is geslagen in het stelsel van het ontslagrecht. In de praktijk komt het hoofdzakelijk neer op een aantal typen gevallen waarin de ontbindende voorwaarde worden afgesproken: het niet langer beschikken over de vereiste papieren (rijbewijs, goedkeuring DNB, toestemming van de politie of AIVD) is de meest gekozen toepassing naar mijn indruk.

Gaat de Wwz verandering brengen in de leer van de Hoge Raad? Er is nog weinig geschreven over deze vraag. De Laat stelt dat de Hoge Raad 'wel eens op zijn schreden terug moet komen vanwege de uitgangspunten van het nieuwe wettelijke stelsel van ontslagrecht. ${ }^{5}$ Welke argumenten zijn hiervoor en -tegen te bedenken?

\section{De Wwz-regels}

In de eerste plaats is van belang dat de wetgever zich hierover niet heeft uitgelaten en je dus zou kunnen zeggen: hij heeft niet gewild verandering aan te brengen (daar waar dat bij andere leerstukken van de Hoge Raad, zoals ten aanzien van artikel 7:628 $\mathrm{BW}$, wel het geval was). Dat argument is echter niet doorslaggevend: het huis van het ontslagrecht is aanzienlijk verbouwd en dat kan betekenen dat op sommige meubels in dat huis een ander licht valt, hoewel niemand ze heeft aangeraakt. Wat is er dan aan het ontslagrecht onder de Wwz veranderd waardoor het niet meer zou kunnen? Daarop luidt mijn antwoord: niets dat naar de letter een dergelijk beding verbiedt.

\section{De letter van de Wwz}

Ik loop de voor de hand liggende bepalingen na. In de eerste plaats kan men denken aan het gesloten stelsel van gronden als bedoeld in artikel 7:669 lid $3 \mathrm{BW}$. Deze gronden zien echter alleen op opzegging (inclusief ontbinding) en niet op een andere beëindigingswijze, zoals het einde van rechtswege. Anders gezegd: artikel 7:669 lid 3 beperkt de beëindigingsgronden, niet de beëindigingswijzen. Ik wil met dit argument niet stellen dat plotseling iedere ontbindende voorwaarde is toegestaan; de rechtspraak onder het oude recht heeft zijn betekenis ook op dit punt niet verloren. Met die beperking voor ogen geldt zelfs, denk ik, dat een als zuivere a-grond geformuleerde ontbindende voorwaarde niet bij voorbaat verboden is wegens artikel 7:669 lid $3 \mathrm{BW}$. Ten tweede zou men kunnen wijzen op de herplaatsingsverplichting die in artikel 7:669 lid 1 BW is geformuleerd. Ook die ziet echter op situaties waarin de werkgever wil opzeggen en niet bij een einde van rechtswege. Zij geldt evenmin na het verlopen van een contract voor bepaalde tijd. In de derde plaats is daar de ontslagvergoeding; vroeger een optie, thans, in de vorm van de transitievergoeding, een recht. Het grappige is dat deze ook aan de werknemer verschuldigd is indien de overeenkomst van rechtswege eindigt en op initiatief van de werkgever niet wordt voortgezet (artikel 7:673 lid $1 \mathrm{BW}$ ). Soms zal daarvan sprake kunnen zijn bij een einde als gevolg van een ontbindende voorwaarde, bijvoorbeeld indien de werknemer nog in aangepaste arbeid door zou kunnen en willen, maar de werkgever dat niet wenst. De kans dat de werknemer een vergoeding krijgt is derhalve hoger dan onder het oude recht, dus de kans dat dit nu plots wel aanleiding vormt voor het verbieden van de ontbindende voorwaarde is uiterst onwaarschijnlijk.

\section{De geest van de Wwz}

Wellicht is het ontslagrecht dan wel naar de geest geslotener geworden, waardoor het toch aannemelijk is dat de Hoge Raad op zijn schreden terugkeert? Dat het wettelijk stelsel strikter is geworden valt te bepleiten, met name door het gesloten stelsel van gronden en de herplaatsingsplicht. Nu zij echter naar de letter niet van toepassing zijn op de ontbindende voorwaarde, is het, net als onder het oude recht, niet aannemelijk dat iedere voorwaarde in strijd is met het stelsel. Maar dat laat nog open dat voorwaarden eerder in strijd zijn met dit stelsel. Daarvoor zijn in ieder geval twee ingangen te bedenken. Ten eerste kan de herplaatsingsplicht via een beroep op artikel 7:611 BW worden toegepast. Dit is in het verleden ook wel eens getracht, maar afgewezen. ${ }^{6}$ Daarbij moet verder worden bedacht dat ook onder het oude recht de herplaatsingsplicht al in zekere mate gold. Kortom: een hoge drempel voor de werknemer. Ten tweede zou men kunnen betogen dat een ontbindende voorwaarde moet passen in een van de gronden van artikel 7:669 lid 3 BW. Men kan dat niet baseren op de (veronderstelde) regel dat de als voorwaarde geformuleerde ontslaggrond ook door het UWV of de kantonrechter zou zijn aanvaard. Een dergelijke regel heeft de Hoge Raad namelijk niet gegeven. Daarbij komt dat de meeste voorwaarden gemakkelijk onder een van de gronden van artikel 7:669 lid $3 \mathrm{BW}$ zullen vallen. Het wegvallen van 'de vereiste papieren' is naar mijn mening een goed voorbeeld van de h-grond, vergelijkbaar met het in de wetsgeschiedenis genoemde geval van het ontbreken van een tewerkstellingsvergunning.

\section{Conclusie}

Ik zie geen reden om te concluderen dat de Mungra- en HTM-leer onder de Wwz zal worden verlaten of vaker tot vernietiging van ontbindende voorwaarden zal leiden.

6. Zoals in Hof Amsterdam 26 augustus 2014, ECLI:NL:GHAMS: 2014:3532.

5. J.J.M. de Laat, 'De ontbindende voorwaarde in het nieuwe ontslagrecht', TRA 2014/100 